\title{
Produktivitas Pengusaha Mikro: Variabel Anteseden dan Pengaruhnya Terhadap Keberlanjutan Kinerja Komunitas Jember Ekonomi Kreatif (JEKa) di Jember
}

\author{
Hary Sulaksono ${ }^{1}$, Tamriatin Hidayah ${ }^{2}$ \\ STIE Mandala, Jember ${ }^{1,2}$ \\ Email : hary@stie-mandala.ac.id ${ }^{1}$, titin@stie-mandala.ac.id ${ }^{2}$
}

\begin{abstract}
The existence of micro businesses plays an important role as a driver of the country's economy. including successfully contributing to the Gross Regional Domestic Product (GRDP) for the district of Jember. At present in the 4.0 era, being promoted is a micro business in the JEKa community that collaborates with the Jember Cooperative Office and UMKM. Aim to the study are: To find out and test the effect of business consulting variables, results marketing facilities, job skills training, issuance of SKUs on the productivity of microbusinesses in the JEKA community in Jember district; To find out and test the effect of micro business productivity variables on the sustainability of performance in the JEKA community in Jember district; To find out and test the effect of business consulting variables, results marketing facilities, job skills training, issuance of SKUs on performance sustainability in the JEKA community in Jember district. Analysis method is Path analysis. The results of this study are Business consultation variables has a significant positive effect on productivity of microbusinesses in Jember Regency, except work skill training; micro business productivity has a significant positive effect on the sustainability of performance in the JEKa community in Jember district; the effect of micro business productivity variables on the sustainability of performance in the JEKa community in Jember district has a significant positive effect on productivity of microbusinesses in Jember Regency, except work skill training.
\end{abstract}

Keywords: Business consultation, Productivity, sustainability of performance, JEKa community

\section{Pendahuluan}

Usaha Mikro adalah usaha produktif milik orang perorangan dan/atau badan usaha perorangan yang memenuhi kriteria sebagaimana diatur dalam Undangundang Nomor 20 Tahun 2008. Dalam perkembangannya, keberadaan usaha mikro sangat berperan penting sebagai penggerak ekonomi negara. Hal ini terbukti dalam data milik Kementerian Koperasi dan UMKM tahun 2018. Disebutkan, peranan Usaha Mikro, Kecil, dan Menengah (UMKM) di bidang perekonomian 
nasionalmencapai hingga 99,9 persen dan penyerapan tenaga kerja mencapai 97 persen.UMKM juga menyumbang terhadap Produk Domestik Bruto (PDB) hingga 60,34 persen dan diperkirakan akan meningkat sebesar 5 persen pada tahun 2019.Peran UMKM berikutnya yang tidak kalah penting adalah memberikan pemasukan bagi negara dalam bentuk devisa. Data dari Kementerian Koperasi dan UKM di tahun 2017 menunjukkan tingginya devisa negara dari para pelaku UMKM. Angkanya pun sangat tinggi, mencapai, Rp 88,45 miliar. Angka ini mengalami peningkatan hingga delapan kali lipat dibandingkan tahun 2016.

Kabupaten Jember sendiri sebagai salah satu kabupaten yang peduli akan nasib UMKM berhasil menyumbang Produk Domestik Regional Bruto (PDRB) sebesar 67.476.071,8 juta di tahun 2018. Jumlah tersebut diketahui mengalami peningkatan dari tahun sebelumnya yakni sebesar 62.513.680.5 juta.Pencapaian tersebut tentunya tidak lepas dari peran serta UMKM yang ada di Kabupaten Jember.Dinas Koperasi dan Usaha Mikro Kabupaten Jember mencatat ada sebanyak 5.790 usaha mikro yang terdaftar mulai dari tahun 2011 hingga tahun 2018.Jenis usahanya pun terbagi dalam beberapa jenis, yaitu di bidang jasa, perdagangan, produksi, pertanian, dan peternakan. Demi untuk mendorong kemajuan usaha, berbagai jenis usaha mikro tersebut kini aktif bergabung dalam komunitas usaha.Keberadaan komunitas usaha tersebut juga bertujuan untuk meningkatan kesejahteraan para anggotanya, yang ditandai dengan meningkatnya produktivitas usaha.Namun demikian meski telah tergabung dalam komunitas usaha, masalah klasik yang dihadapi para pengusaha mikro ini seringkali muncul.

Sementara itu temuan dari penelitian terdahulu adalah Ria Irawati (2018), Temuan yang diperoleh bahwa Ada pengaruh secara simultan dan parsial antara pelatihan dan pembinaan terhadap pengembangan usaha kecil. Sedangkan temuan Meida Nur Rahma (2018) yang diperoleh bahwa secara parsial variabel pelatihan, pendampingan, dan pembinaan dari Pemerintah Kota Yogyakarta memiliki pengaruh positif terhadap pendapatan UMKM. Sementara, Mohammad Adrian et al (2017), Temuan yang diperoleh bahwa pendampingan usaha berpengaruh terhadap kinerja UMKM sebesar $74 \%$. Sedangkan sisanya $26 \%$ dipengaruhi oleh faktor lain seperti kompetensi kewirausahaan dan SDM. Naritza Mirlithia 
Karauwanet a.l (2016),. Temuan yang diperoleh bahwa Kemampuan sumberdaya manusia yang dimiliki Dinas Koperasi dan Usaha Mikro, Kecil dan Menengah Kota Manado dalam pelaksanaan program-program pengembangan Usaha Kecil dan Menengah belum maksimal karena keterbatasan jumlah pegawai yang masih sedikit yaitu tujuh orang pegawai. Tulus Haryono et al (2013), Temuan yang diperoleh bahwa kesembilan variabel independen (keterampilan manajerial, kemampuan akumulasi modal, kepemimpinan, inovasi, keberanian menanggung resiko, lingkungan ekonomi, lingkungan fisik, lingkungan organisasi, dan karakteristik individu) memiliki perbedaan pengaruh terhadap perilaku kewirausahaan para pengusaha di tiga kelompok UKM (tekstil, kayu, dan makanan) amatan, namun perilaku kewirausahaan berpengaruh signifikan pada kinerja usaha di tiga kelompok UKM.

Berdasarkan hasil kajian awal dari Dinas Koperasi Usaha Mikro Kabupaten Jember, diketahui bahwa ada empat permasalahan yang dihadapi oleh usaha mikro, yaitu pemasaran, permodalan, keterampilan teknik dan manajemen. Pembinaan usaha mikro tentunya harus mengarah pada pemecahan atau memberikan jalan keluar bagi empat permasalahan yang dihadapi usaha mikro tersebut. Sesuai dengan undang-undang nomor 32 Tahun 2004 tentang pemerintahan daerah maka pembinaan usaha mikro menjadi tugas dan tanggung jawab pemerintah daerah. Pemerintah daerah melimpahkan tugas pembinaan usaha tersebut kepada Dinas Koperasi dan Usaha Mikro sebagai unsur pelaksana otonomi daerah. Pembinaan yang dilakukan dapat berupa konsultasi bisnis, fasilitasi pemasaran hasil produksi, pelatihan keterampilan, dan penerbitan SKU.Persoalan yang kemudian muncul adalah apakah pembinaan yang dilakukan Dinas Koperasi dan Usaha Mikro Kabupaten Jember tersebut efektif atau tidak. Artinya, pembinaan itu berdampak positif pada meningkatnya produktivitas pengusaha mikro atau tidak. Penelitian ini bermaksud untuk mengkaji hubungan antara pembinaan usaha mikro oleh Dinas Koperasi dan Usaha Mikro dengan produktivitas pengusaha mikro yang tergabung dalam komunitas JEKa di Kabupaten Jember.

Peranan pelaku usaha mikro yang tergabung dalam komunitas Jember Ekonomi Kreatif (JEKA) menjadi penting dari peran serta akademisi, Badan 
pemerintah yang ditunjuk yaitu Dinas Koperasi dan Usaha Mikro Kabupaten Jember tersebut efektif atau tidak. Sementara itu revolusi 4.0 memberikan tantangan sekaligus peluang tidak terkecuali sektor pendididikan tinggi, pelaku usaha maupun sektor pemerintah. Kinerja suatu entitas masing-masing terkait dengan kinerja sumberdaya manusia (SDM) nya. SDM merupakan bagian yang sangat penting dalam peninggkatan dan pengembangan suatu organisasi. Suatu lembaga atau organisasi yang memiliki SDM dengan kinerja yang baik akan lebih mudah dalam upaya pencapaian tujuan organisasinya.

Adapun tujuan penelitian ini adalah 1). Untuk mengetahui dan menguji pengaruh variabel konsultasi bisnis, fasilitas pemasaran hasil, pelatihan ketrampilan kerja, penerbitan SKU terhadap produktivitas usaha mikro pada komunitas JEKA di kabupaten Jember; 2). Untuk mengetahui dan menguji pengaruh variabel produktivitas usaha mikro terhadap keberlanjutan kinerja pada komunitas JEKA di kabupaten Jember; 3). Untuk mengetahui dan menguji pengaruh variabel konsultasi bisnis, fasilitas pemasaran hasil, pelatihan ketrampilan kerja, penerbitan SKU terhadap keberlanjutan kinerja pada komunitas JEKA di kabupaten Jember

\section{Tinjauan Pustaka}

\subsection{Dinas Koperasi dan Usaha Mikro}

Sebagaimana tercantum dalam Peraturan Bupati Jember Nomor 43 Tahun 2016, kedudukan Dinas Koperasi dan Usaha Mikro Kabupaten Jember adalah sebagai berikut :

(1) Dinas merupakan unsur pelaksana urusan pemerintahan dibidang koperasi, usaha kecil dan menengah.

(2) Dinas dipimpin oleh kepala dinas yang berkedudukan dibawah dan bertanggungjawab kepada Bupati melaluiSekretaris Daerah.

(3) Dinas sebagaimana dimaksud pada ayat (1) mempunyai tugasmelaksanakan urusan pemerintahan yang menjadikewenangan daerah di bidang koperasi, usaha kecil danmenengah.

(4) Dinas dalam melaksanakan tugas sebagaimana dimaksud pada ayat (3) menyelenggarakan fungsi: 
a. perumusan kebijakan daerah di bidang koperasi, usahakecil dan menengah;

b. pelaksanaan kebijakan daerah di bidang koperasi, usahakecil dan menengah;

c. pelaksanaan evaluasi dan pelaporan daerah di bidangkoperasi, usaha kecil dan menengah;

d. pelaksanaan administrasi Dinas di bidang koperasi, usahakecil dan menengah;dan

e. pelaksanaan fungsi lain yang diberikan oleh Bupati terkaitdengan tugas dan fungsinya.

\subsection{Usaha Mikro}

Usaha Mikro sebagaimana dijelaskan dalam Undang-undang Nomor 20 Tahun 2008 adalah usaha produktif milik orang perorangandan/atau badan usaha perorangan yang memenuhi kriteriaUsaha Mikro sebagaimana diatur dalam Undang-Undang tersebut dengan kriteria sebagai berikut: a) Memiliki kekayaan bersih paling banyak Rp 50.000.000,00 (lima puluh juta rupiah) tidak termasuk tanah dan bangunan tempat usaha; atau b) Memiliki hasil penjualan tahunan paling banyak $\operatorname{Rp} 300.000 .000,00$ (tiga ratus juta rupiah).

\subsection{Pembinaan dan Pengembangan Usaha Mikro}

Pembinaan dan pengembangan usaha mikro telah dilakukan sejak lama dan telah mengalami beberapa perubahan. Dahulu usaha mikro dibina oleh Departemen Perindustrian dan Departemen Perdagangan. Setelah melalui perubahan beberapa kali maka semenjak beberapa tahun terakhir pembinaan terhadap UK dilakukan bersama dengan usaha menengah (UM) dan Koperasi di bawah Departemen Koperasi, Usaha Kecil dan Menengah.

Pemerintah melakukan pembinaan dan pengembangan terhadap usaha mikro dengan mengeluarkan Peraturan Pemerintah Republik Indonesia No. 32 Th. 1998 yang mengatur mengenai lingkup, tata cara, dan pelaksanaan pembinaan dan pengembangan usaha mikro. Adapun pembinaan dan pengembangan usaha mikro dilakukan oleh pemerintah, dunia usaha dan masyarakat, baik secara sendirisendiri maupun bersama-sama, dan dilakukan secara terarah dan terpadu serta 
berkesinambungan untuk mewujudkan usaha mikro yang tangguh, mandiri serta dapat berkembang.

Ruang lingkup pembinaan dan pengembangan usaha mikro meliputi bidang produksi dan pengolahan, pemasaran, sumber daya manusia, dan teknologi.

\subsection{Pembinaan}

Pembinaan berasal dari kata "bina" yang mendapat awalan pe- dan akhiran -an, yang berarti bangun/bangunan. Dalam Kamus Besar Bahasa Indonesia pembinaan berarti membina, memperbaharui atau proses, perbuatan, cara membina, usaha, tindakan dan kegiatan yang dilakukan secara berdaya guna dan berhasil guna untuk memperoleh hasil yang lebih baik.

Pembinaan adalah sebuah proses sistematis untuk mengubah perilaku kerja seorang/sekelompok pegawai dalam usaha meningkatkan kinerja organisasi. Pembinaan terkait dengan keterampilan dan kemampuan yang diperlukan untuk pekerjaan yang sekarang dilakukan. Pembinaan berorientasi ke masa sekarang dan membantu pegawai untuk menguasai keterampilan dan kemampuan (konpetensi) yang spesifik untuk berhasil dalam pekerjaannya.

\subsection{Produktivitas}

Menurut Kurniawan (dalam Anoraga, Pandji. 2007:238) produktivitas merupakan kemampuan perusahaan untuk menghasilkan output yang diinginkan dengan dasar umum ekonomi, efisiensi dan optimalisasi sumber daya yang ada sehingga mampu menghasilkan laba.Produktivitas dapat digunakan sebagai tolak ukur keberhasilan suatu industri atau UKM dalam menghasilkan barang atau jasa. Sehingga semakin tinggi perbandingannya, berarti semakin tinggi produk yang dihasilkan. Ukuran-ukuran produktivitas bisa bervariasi, tergantung pada aspekaspek output atau input yang digunakan sebagai agregat dasar, misalnya: indeks produktivitas buruh, produktivitas biaya langsung, produktivitas biaya total, produktivitas energi, produktivitas bahan mentah, dan lain-lain.

\section{Metode Penelitian}

\subsection{Gambaran Umum Objek Penelitian}

Jember Ekonomi Kreatif (JEKa) adalah salah satu komunitas industri yang mengembangkan produk-produk kreatif lokal. Komunitas industri kreatif ini 
diadakan guna menghasilkan pendapatan asli daerah.Dalam JEKa terdapat beberapa divisi, yakni divisi keagamaan, sosial, ekonomi, kreatif, dan industri kreatif.Beberapa kegiatan yang rutin diadakan oleh JEKa yakni Kopdar (Kopi Darat) antar sesama anggota yang bertempat di Jl. Singosari, Kec. Sumbersari, Kab. Jember dan juga Pasar Kreatif.Dalam kegiatan Pasar Kreatif, komunitas JEKa membuka stand bazar (lapak) yang menjual berbagai macam produk lokal seperti kerajinan, makanan, minuman, oleh-oleh, dan aneka aksesoris serta souvenir. Tujuannya yakni untuk memperkenalkan produk-produk asli kota Jember dengan varian bentuk dan kemasan yang berbeda agar menarik minat masyarakat lebih banyak lagi.

\subsection{Populasi dan Sampel}

\section{Populasi}

Populasi adalah wilayah generalisasi yang terdiri atas obyek/subyek yang mempunyai kualitas dan karakteristik tertentu yang ditetapkan oleh peneliti untuk dipelajari dan kemudian ditarik kesimpulannya. Populasi bukan hanya orang tetapi juga obyek dan benda-benda alam yang lain. Populasi juga bukan sekedar jumlah yang ada pada obyek/subyek yang dipelajari, tetapi meliputi seluruh karakteristik/sifat yang dimiliki oleh subyek atau obyek itu (Sugiyono, 2004:90). Populasi dalam penelitian ini adalah semua anggota yang tergabung dalam komunitas Jember Ekonomi Kreatif (JEKa) sebanyak 70 pengusaha.

\section{Sampel}

Sampel adalah bagian dari jumlah dan karakteristik yang dimiliki oleh populasi yang menjadi subjek penelitian tersebut (Sugiyono, 2005). Menentukan dan menetapkan besarnya sampel penelitian ada rumus dan ketentuannya. Hal ini dikemukakan oleh Sugiyono (2005), bahwa :1) Ukuran sample yang layak dalam penelitian adalah antara $30 \mathrm{~s} / \mathrm{d}$ 500; 2) Bila sampel dibagi dalam kategori (misalnya : pria-wanita, pegawai negeri-swasta,) maka jumlah sampel setiap kategori minimal 30; 3) Bila dalam penelitian akan melakukan analisis dengan multivariate (korelasi atau regresi ganda misalnya), maka jumlah anggota sampel minimal 10 kali dari jumlah variabel yang diteliti; 4) Untuk penelitian eksperimen yang sederhana, yang menggunakan kelompok eksperimen dan kelompok kontrol, maka jumlah anggota 
sampel masing-masing antara $10 \mathrm{~s} / \mathrm{d} 20$. Karena dalam penelitian ini metode analisis yang digunakan yakni Analisis Linear Berganda dengan menggunakan 4 variabel, maka peneliti menentukan jumlah sampel penelitian yakni sebanyak: $10 \mathrm{x}$ $4=40$ anggota .

\subsection{Definisi Operasional Variabel}

Definisi operasional pada penelitian adalah unsur penelitian yang terkait dengan variabel yang terdapat dalam judul penelitian atau yang tercakup dalam paradigma penelitian sesuai dengan hasil perumusan masalah. Teori ini dipergunakan sebagai landasan atau alasan mengapa suatu yang bersangkutan memang bisa memengaruhi variabel tak bebas (Supranto, 2003: 322).

Definisi operasional variabel penelitian yang digunakan oleh penulis adalah sebagai berikut :

\section{Konsultasi Bisnis (X1)}

Merupakan kegiatan konsultasi kepada suatu organisasi/ lembaga/ perusahaan, agar semakin berkembang dan efisien.Kegiatan ini mengidentifikasi masalah dan memberikan solusi terhadap permasalahan tersebut, serta membuat perencanaan bisnis ke depan agar bisa memenuhi target yang diinginkan organisai/lembaga/perusahaan.

Berdasarkan Indikator Kinerja Utama Dinas Koperasi dan Usaha Mikro Kabupaten Jember Tahun 2018, variabel pengaruh ini diukur dengan indikator sebagai berikut :

1. Sosialisasi dukungan informasi penyediaan permodalan

2. Sosialisasi pemanfaatan fasilitasi pemerintah untuk usaha mikro

3. Sosialisasi Pengurusan Ijin Pangan Industri Rumah Tangga (PIRT)

4. Sosialisasi Hak Atas Kekayaan Intelektual (HAKI)

5. Fasilitasi permasalahan proses produksi

\section{Fasilitasi Pemasaran Hasil Produksi (X2)}

Program pada Dinas Koperasi dan Usaha Mikro Kabupaten Jember untuk membantu agar para pelaku usaha tidak kesulitan dalam memasarkan hasil produksinya, sehingga menarik minat masyarakat untuk membeli produk tersebut.Kegiatan tersebut dapat dilakukan melalui berbagai macam metode 
pemasaran seperti lewat media online, menyediakan tempat untuk memamerkan hasil produk, dan partisipasi dalam kegiatan pameran.

Berdasarkan indikator kinerja utama Dinas Koperasi dan Usaha Mikro Kabupaten Jember Tahun 2018, variabel pengaruh ini diukur dengan indikator, sebagai berikut:

1. Peningkatan omzet penjualan produk

2. Fasilitasi peningkatan kemitraan usaha bagi usaha mikro dengan perusahaan asing

3. Fasilitasi pemasaran melalui gelar produk, galeri produk, temu bisnis dan media online

\section{Pelatihan Keterampilan (X3)}

Suatu usaha yang dilakukan guna memberikan pengetahuan baru, meningkatkan keterampilan dan kemampuan usaha mikro dalam mengembangkan produknya.Pelatihan tersebut juga dapat mendorong timbulnya beberapa kegiatan ekonomi melalui tumbuhnya usaha yang dapat memenuhi kebutuhan masyrakat dan bahkan perusahaan.

Berdasarkan Indikator Kinerja Utama Dinas Koperasi dan Usaha Mikro Kabupaten Jember Tahun 2018, variabel pengaruh ini diukur dengan indikatorsebagai berikut:

1. Peningkatan kualitas produksi

2. Penyediaan peralatan pelatihan

3. Inovasi dalam pengembangan usaha

\section{Penerbitan Surat Keterangan Usaha (SKU) (X4)}

Salah satu bentuk legalitas usaha yang dapat digunakan sebagai persyaratan dokumen jika ingin mengajukan pinjaman kredit ke bank atau lembaga keuangan lain untuk keperluan mengembangkan usaha.

Berdasarkan indikator kinerja utama Dinas Koperasi dan Usaha Mikro Kabupaten Jember Tahun 2018, variabel pengaruh ini diukur dengan indikator sebagai berikut :

1. Sosialisasi SKU melalui mobil klinik

2. Fasilitasi kemudahan pembuatan SKU 


\section{Produktivitas $\left(\mathbf{Y}_{2}\right)$}

Merupakan kemampuan perusahaan untuk menghasilkan output yang diinginkan dengan dasar umum ekonomi, efisiensi dan optimalisasi sumber daya yang ada sehingga mampu menghasilkan laba (Pandji, 2007:238).

Variabel terikat ini diukur dengan indikator sebagai berikut :

1. Bertambahnya jumlah produk yang dihasilkan per-orang perhari; Bertambahnya mutu disain produk barang atau pelayanan produk jasa; Bertambahnya semangat kerja para pekerja;

Bertambahnya etos kerja para pekerja; Adanya buku catatan transaksi dan keluar masuknya uang yang memenuhi standar administrasi keuangan minimal; Adanya catatan inventaris atau asset yang dimiliki usaha mikro

\section{Keberlanjutan Kinerja Komunitas JEKA ( $\left.\mathbf{Y}_{1}\right)$}

Merupakan kemampuan komunitas untuk dapat eksis, melalui permodalan oleh anggotanya, adanya peningkatan kualitas produksi, peningkatan pengetahuan dan ketrampilan, adanya inovasi oleh anggota.

\subsection{Metode Pengumpulan Data}

Untuk memperoleh data yang akurat digunakan alat pengumpulan data yang tepat agar memperoleh kesimpulan yang tidak menyesatkan. Dalam penelitian ini digunakan tiga metode pengumpulan data yaitu :

\section{Metode Kuesioner}

Metode pengumpulan data dengan cara mengajukan pertanyaan secara tertulis untuk dijawab secara tertulis pula oleh responden. Dalam penelitian ini digunakan kuesioner terstruktur dengan pertanyaan-pertanyan tertutup. Skala yang digunakan dalam penelitian ini adalah skala Likert, yakni skala yang digunakan untuk mengukur tanggapan atau respon seseorang tentang obyek dari mulai sangat negatif hingga sangat positif dengan lima alternatif jawaban diberi skor sebagai berikut (Suliyanto, 2008:83) :

Sangat Setuju (SS): 5; Setuju (S): 4; Kurang Setuju (KS) : 3; Tidak Setuju (TS): 2; Sangat Tidak Setuju (STS) : 1

\section{Wawancara}

Metode wawancara digunakan untuk melengkapi data yang belum 
terungkap dalam angket. Menurut Esterberg dalam Sugiyono (2013:231) wawancara merupakan pertemuan dua orang untuk bertukar informasi dan ide melalui Tanya jawab, sehingga dapat dikonstruksikan makna dalam suatu topic tertentu.Dalam melakukan wawancara, pengumpul data telah menyiapkan instrumen penelitian berupa pertanyaan untuk memperoleh data yang menunjang penelitian tersebut.

\section{Dokumentasi}

Menurut Sugiyono (2013:240) dokumen merupakan catatan peristiwa yang sudah berlalu.Dokumen bisa berbentuk tulisan, gambar, atau karya-karya menumental dari seorang. Dokumen yang berbentuk tulisan misalnya catatan harian, sejarah kehidupan (life histories), ceritera, biografi, peraturan, kebijakan.Dokumen yang berbentuk gambar misalnya foto, gambar hidup, sketsa dan lain-lain.Dokumen yang berbentuk karya misalnya karya seni, yang dapat berupa gambar, patung, film dan lain-lain.Studi dokumen merupakan pelengkap dari penggunaan metode observasi dan wawancara.

\section{Studi Pustaka}

Peneliti dalam melakukan penelitian yang dilakukan juga melakukan pengumpulan data sekunder yang diperoleh dari dokumen maupun sumber data sekunder lainnya, termasuk telaah literatur yang relevan agar dapat mendukung data primer yang diperoleh melalui kuesioner, observasi, maupun wawancara yang ditabulasi dalam bentuk data berupa dokumen.

\subsection{Metode Analisis Data}

\section{Analisis Kuantitatif}

\section{Uji Validitas}

Uji validitas digunakan untuk mengukur sah atau tidaknya suatu kuesioner. Suatu kuesioner dikatakan valid jika pada kuesioner mampu mengungkapkan sesuatu yang akan diukur oleh kuesioner tersebut (Ghozali, 2011:52). Dasar pengambilan keputusan yaitu sebagai berikut : Jika $r$ hitung > r table maka dikatakan valid; Jika $r$ hitung < t table maka dikatakan tidak valid

\section{Uji Reliabilitas}

Uji Reliabilitas sebenarnya adalah alat untuk mengukur suatu kuesioner 
yang merupakan indikator dari variabel konstruk.Suatu kuesioner dikatakan reliabel atau handal jika jawaban seseorang terhadap pertanyaan adalah konsisten atau stabil dari waktu ke waktu (Ghozali, 2011:47).Pengukuran reliabilitas pada penelitian ini menggunakan program SPSS 16 dengan uji statistic cronbach alpha. Suatu konstruk atau variable dikatakan reliable jika memberikan nilai cronbach alpha > 0, 60 (Praba:2011).

\section{Hasil Dan Pembahasan}

Responden dalam penelitian ini adalah sebanyak 40 pengusaha mikro di Kabupaten Jember. Karakteristik responden sebagai berikut:

Tabel 3.1 Karakteristik Responden

\begin{tabular}{|c|c|c|c|}
\hline Karakteristik & $\begin{array}{l}\text { Distribusi } \\
\text { Responden }\end{array}$ & Frekuensi & Persentase $(\%)$ \\
\hline \multirow{3}{*}{ Jenis Kelamin } & Laki-laki & 19 & $48 \%$ \\
\hline & Perempuan & 21 & $53 \%$ \\
\hline & Jumlah & 40 & $100 \%$ \\
\hline \multirow{4}{*}{ Usia } & 21-30 tahun & 12 & $30 \%$ \\
\hline & $31-40$ tahun & 15 & $38 \%$ \\
\hline & 41-50 tahun & 13 & $33 \%$ \\
\hline & Jumlah & 40 & $100 \%$ \\
\hline \multirow{5}{*}{ Pendidikan } & SMA & 23 & $58 \%$ \\
\hline & D3 & 5 & $13 \%$ \\
\hline & S1 & 11 & $28 \%$ \\
\hline & S2 & 1 & $3 \%$ \\
\hline & Jumlah & 40 & $100 \%$ \\
\hline \multirow{9}{*}{ Jenis Usaha } & Minuman & 3 & $8 \%$ \\
\hline & Makanan Ringan & 4 & $10 \%$ \\
\hline & Kerajinan & 11 & $28 \%$ \\
\hline & Kue Kering & 5 & $13 \%$ \\
\hline & Pakan Ternak & 1 & $3 \%$ \\
\hline & Produsen & 1 & $3 \%$ \\
\hline & Kuliner & 10 & $25 \%$ \\
\hline & Jasa & 5 & $13 \%$ \\
\hline & Jumlah & 40 & $100 \%$ \\
\hline Intensitas & 1 thn & 19 & $48 \%$ \\
\hline
\end{tabular}




\begin{tabular}{llll}
\hline pembinaan & \multicolumn{1}{l}{\begin{tabular}{l} 
thn \\
\cline { 2 - 4 } 3 thn
\end{tabular}} & 7 & $15 \%$ \\
\cline { 2 - 4 } & 4 thn & 6 & $18 \%$ \\
\hline 5 thn & 2 & $15 \%$ \\
\hline Jumlah & $\mathbf{4 0}$ & $\mathbf{1 0 0 \%}$ \\
\hline
\end{tabular}

Sumber data: lampiran (data diolah)

Berdasarkan di atas, dapat dilihat bahwa mayoritas responden berjenis kelamin perempuan dengan presentase 53\% atau 21 responden dari 40 total keseluruan responden, berusia rata-rata 31 - 40 tahun dengan persentase $38 \%$ atau 15 responden dengan usia rata-rata tersebut, berpendidikan jenjang SMA dengan persentase $58 \%$ atau 23 responden, memiliki usaha di bidang kerajinan dengan presentase $28 \%$ atau 11 responden dan intensitas waktu pembinaan selama 1 tahun dengan persentase $48 \%$ atau 19 responden. Artinya, mayoritas responden umumnya adalah perempuan, kalangan usia dewasa bekisar 31 - 40 tahun dengan tingkat pendidikan SMA dan berprofesi sebagai pengkerajin. Hal ini dikarenakan pengusaha mikro di Kabupaten Jember yang masih dianggap butuh bimbingan dari para ahli dan tentunya masih butuh banyak pelatihan keterampilan kerja. Intensitas waktu pembinaan responden adalah sekitar 1 tahun yang bisa dikatakan tergolong baru dalam melakukan bisnis. Bisa dikatakan intensitas waktu pembinaan tergolong baru, karena hal ini disebabkan kesadaran akan usaha tergolong masih rendah.

\section{Tabel 3.2}

\section{Analisis Jalur}

\begin{tabular}{|c|c|c|c|c|}
\hline Uraian & Hubungan & Koefisien Jalur & $\boldsymbol{\beta}$ & Sig. \\
\hline \multirow{4}{*}{$\begin{array}{c}\text { Jalur pengaruh } \\
\text { langsung variabel X } \\
\text { terhadap Y2 }\end{array}$} & $\mathrm{X}_{1} \rightarrow \mathrm{Y} 2$ & $\beta_{\mathrm{y} 2 \mathrm{x} 1}$ & $-0,748$ & 0,008 \\
\hline & $\mathrm{X}_{2} \rightarrow \mathrm{Y} 2$ & $\beta_{\mathrm{y} 2 \times 2}$ & 0,555 & 0,002 \\
\hline & $\mathrm{X}_{3} \rightarrow \mathrm{Y} 2$ & $\beta_{\mathrm{y} 2 \times 3}$ & $-0,354$ & 0,229 \\
\hline & $\mathrm{X}_{4} \rightarrow \mathrm{Y} 2$ & $\beta_{\mathrm{y} 2 \times 4}$ & 0,666 & 0,029 \\
\hline \multirow{4}{*}{$\begin{array}{c}\text { Jalur pengaruh } \\
\text { langsung variabel X } \\
\text { terhadap Y1 }\end{array}$} & $\mathrm{X}_{1} \rightarrow \mathrm{Y} 1$ & $\beta_{\mathrm{y} 1 \times 1}$ & 0,364 & 0,001 \\
\hline & $\mathrm{X}_{2} \rightarrow \mathrm{Y} 1$ & $\beta_{\mathrm{y} 1 \times 2}$ & 0,308 & 0,002 \\
\hline & $\mathrm{X}_{3} \rightarrow \mathrm{Y} 1$ & $\beta_{\mathrm{y} 1 \times 3}$ & 0,075 & 0,488 \\
\hline & $\mathrm{X}_{4} \rightarrow \mathrm{Y} 1$ & $\beta_{\mathrm{y} 1 \times 4}$ & 0,249 & 0,031 \\
\hline $\begin{array}{c}\text { Jalur pengaruh } \\
\text { langsung variabel Y2 } \\
\text { terhadap Y1 }\end{array}$ & $\mathrm{Y} 2 \rightarrow \mathrm{Y} 1$ & $\beta_{\mathrm{y} 1 \mathrm{y} 2}$ & $-0,235$ & 0,049 \\
\hline
\end{tabular}


Berdasarkan Tabel di atas, didapatkan model jalur persamaan struktural sebagai berikut:

$$
\begin{aligned}
& Z=-0,748 X_{1}+0,555 X_{2}-0,354 X_{3}+0,666 X_{4}+e \quad \ldots \ldots \ldots \ldots . .(\text { persamaan } 1) \\
& Y=0,364 X_{1}+0,308 X_{2}+0,075 X_{3}+0,249 X_{4}-0,235 Z+e \ldots \ldots(\text { persamaan } 2)
\end{aligned}
$$

Seluruh jalur pada Tabel di atas kecuali jalur $\beta_{\mathrm{y} 2 \times 3}$ dan $\beta_{\mathrm{y} 1 \times 3}$ memiliki nilai signifikansi lebih dari 0,05 ( $\mathrm{p}>0,05)$ atau merupakan merupakan jalur yang tidak signifikan. Berdasarkan ketentuan trimming theory, jalur yang tidak signifikan akan dihapus sebelum pengaruh langsung dan tidak langsung diuji. Maka jalur $\beta_{\mathrm{y} 2 \times 3}$ dan $\beta_{\mathrm{y} 1 \times 3}$ harus dihapus.

\section{Uji Hipotesis (Uji t)}

Tabel Hasil Uji Hipotesis

\begin{tabular}{cccccc}
\hline Hipotesis & Hubungan & t-hitung & $\boldsymbol{\beta}$ & Sig. & Hasil \\
\hline $\mathrm{H}_{1}$ & $\mathrm{X}_{1} \rightarrow \mathrm{Y} 2$ & $-2,825$ & $-0,748$ & 0,008 & Didukung \\
\hline $\mathrm{H}_{2}$ & $\mathrm{X}_{2} \rightarrow \mathrm{Y} 2$ & 3,336 & 0,555 & 0,002 & Didukung \\
\hline $\mathrm{H}_{3}$ & $\mathrm{X}_{3} \rightarrow \mathrm{Y} 2$ & $-1,232$ & $-0,354$ & 0,226 & Tidak Didukung \\
\hline $\mathrm{H}_{4}$ & $\mathrm{X}_{4} \rightarrow \mathrm{Y} 2$ & 2,272 & 0,666 & 0,029 & Didukung \\
\hline $\mathrm{H}_{5}$ & $\mathrm{X}_{1} \rightarrow \mathrm{Y} 1$ & 3,642 & 0,364 & 0,001 & Didukung \\
\hline $\mathrm{H}_{6}$ & $\mathrm{X}_{2} \rightarrow \mathrm{Y} 1$ & 3,407 & 0,308 & 0,002 & Didukung \\
\hline $\mathrm{H}_{7}$ & $\mathrm{X}_{3} \rightarrow \mathrm{Y} 1$ & 0,701 & 0,075 & 0,488 & Tidak Didukung \\
\hline $\mathrm{H}_{8}$ & $\mathrm{X}_{4} \rightarrow \mathrm{Y} 1$ & 2,248 & 0,249 & 0,031 & Didukung \\
\hline $\mathrm{H}_{9}$ & $\mathrm{Y} 2 \rightarrow \mathrm{Y} 1$ & $-2,043$ & $-0,235$ & 0,049 & Didukung \\
\hline
\end{tabular}

Kriteria penerimaan hipotesis secara korelasi adalah apabila $\mid t$-hitung $\mid>t$-tabel dan nilai signifikansi kurang dari 0,05 (Sig. < 0,05). Maka dari itu, dari nilai tersebut dapat diketahui bahwa hipotesis yang didukung adalah $\mathrm{H}_{1}, \mathrm{H}_{2}, \mathrm{H}_{4}, \mathrm{H}_{5}, \mathrm{H}_{6}, \mathrm{H}_{8}$, dan $\mathrm{H}_{9}$, sedangkan hipotesis yang tidak didukung adalah $\mathrm{H}_{3}$ dan $\mathrm{H}_{7}$. Hal ini berarti bahwa variabel pelatihan keterampilan tidak berpengaruh terhadap produktivitas maupun kinerja. Hasil analisis jalur dapat dilihat pada gambar berikut: 


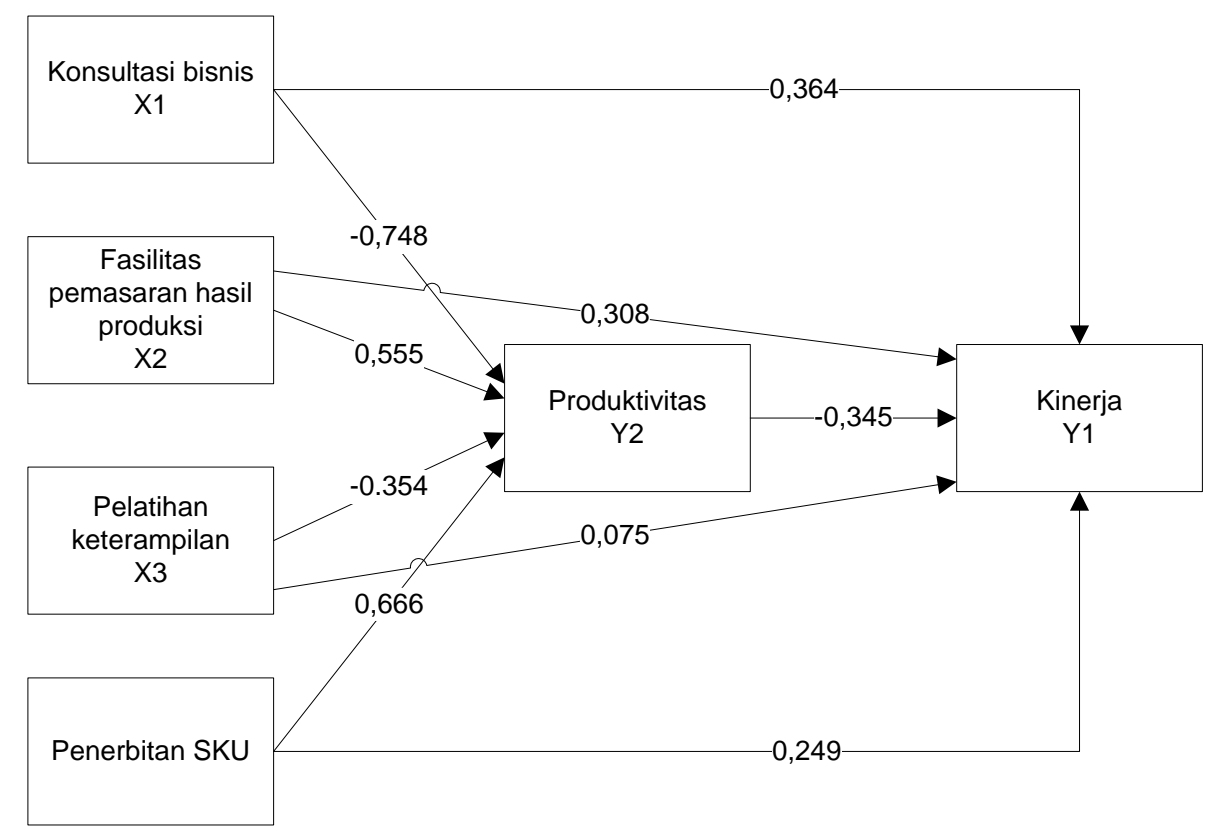

Gambar 4.6 Hasil Uji Analisis Jalur

\section{Trimming Theory}

Trimming theory adalah model yang digunakan untuk memperbaiki suatu model struktur analisis jalur dengan cara mengeluarkan dari model variabel eksogen yang koefisien jalurnya tidak signifikan. Berdasarkan ketentuan trimming theory, jalur yang tidak signifikan akan dihapus sebelum pengaruh langsung dan tidak langsung diuji. Maka jalur $\beta_{\mathrm{y} 2 \times 3}$ dan $\beta_{\mathrm{y} 1 \times 3}$ harus dihapus.

Tabel 3.4 : Trimming Theory

\begin{tabular}{ccccccl}
\hline \multicolumn{3}{c}{$\begin{array}{c}\text { Standarized } \\
\text { Jalur }\end{array}$} & Beta & Sig & $\boldsymbol{\alpha}$ & Keterangan \\
\hline $\mathrm{X} 1$ & $\rightarrow$ & $\mathrm{Y} 2$ & 0,713 & 0,011 & 0,05 & Signifikan \\
\hline $\mathrm{X} 2$ & $\rightarrow$ & $\mathrm{Y} 2$ & 0,500 & 0,004 & 0,05 & Signifikan \\
\hline $\mathrm{X} 4$ & $\rightarrow$ & $\mathrm{Y} 2$ & 0,431 & 0,002 & 0,05 & Signifikan \\
\hline $\mathrm{X} 1$ & $\rightarrow$ & $\mathrm{Y} 1$ & 0,358 & 0,001 & 0,05 & Signifikan \\
\hline $\mathrm{X} 2$ & $\rightarrow$ & $\mathrm{Y} 1$ & 0,315 & 0,001 & 0,05 & Signifikan \\
\hline $\mathrm{X} 4$ & $\rightarrow$ & $\mathrm{Y} 1$ & 0,298 & 0,001 & 0,05 & Signifikan \\
\hline $\mathrm{Y} 2$ & $\rightarrow$ & $\mathrm{Y} 1$ & 0,228 & 0,003 & 0,05 & Signifikan \\
\hline
\end{tabular}


Berdasarkan Tabel di atas Untuk menganalisis jalur pertama dapat dijelaskan bahwa antara konsultasi bisnis $\left(\mathrm{X}_{1}\right)$ dengan produktivitas (Y2) memiliki pengaruh yang signifikan. Hal tersebut dapat diketahui dengan hasil nilai signifikan yaitu 0,011 lebih kecil dari $\alpha=0,05$. Jalur kedua antara fasilitas pemasaran hasil produk $\left(\mathrm{X}_{2}\right)$ dengan produktivitas $(\mathrm{Y} 2)$ memiliki pengaruh yang signifikan yaitu sebesar 0,004 lebih kecil dari $\alpha=0,05$. Jalur ketiga antara penerbitan SKU $\left(\mathrm{X}_{4}\right)$ dengan produktivitas (Y2) memiliki pengaruh yang signifikan yaitu sebesar 0,002 lebih kecil dari $\alpha=0,05$. Jalur keempat antara konsultasi bisnis $\left(\mathrm{X}_{1}\right)$ dengan kinerja (Y1) memiliki pengaruh yang signifikan sebesar 0,001 yaitu lebih kecil dari $\alpha=$ 0,05. Jalur kelima antara fasilitas pemasaran hasil produk $\left(\mathrm{X}_{2}\right)$ dengan kinerja (Y1) memiliki pengaruh yang signifikan yaitu sebesar 0,001 yaitu lebih kecil dari $\alpha=$ 0,05. Jalur keenam antara penerbitan SKU $\left(\mathrm{X}_{4}\right)$ dengan kinerja (Y1) memiliki pengaruh yang signifikan yaitu sebesar 0,001 yaitu lebih kecil dari $\alpha=0,05$. Jalur ketujuh antara produktivitas (Y2) dengan kinerja (Y1) memiliki pengaruh yang signifikan yaitu sebesar 0,003 . Setelah dilakukan penghapusan jalur $\beta_{\mathrm{yx} 2}$ yang tidak signifikan, didapatkan persamaan struktural Y yang baru yaitu:

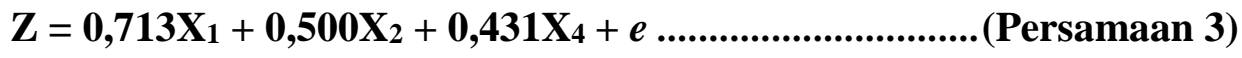

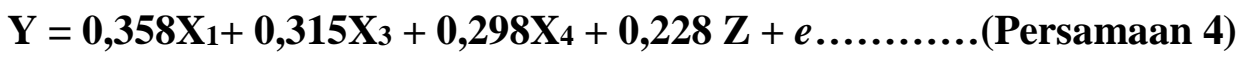

Berdasarkan hasil trimming theory, apabila semua jalur sudah signifikan maka dilakukan perhitungan pengaruh langsung dan tidak langsung. Proses perhitungannya adalah sebagai berikut:

a. Pengaruh Langsung (Direct Effect)

1) Pengaruh langsung variabel konsultasi bisnis terhadap produktivitas adalah sebesar 0,713 .

2) Pengaruh langsung variabel fasilitas pemasaran hasil produksi terhadap produktivitas adalah sebesar 0,500.

3) Pengaruh langsung variabel penerbitan SKU terhadap produktivitas adalah sebesar 0,431 .

4) Pengaruh langsung variabel konsultasi bisnis terhadap kinerja adalah sebesar 0,358

5) Pengaruh langsung variabel fasilitas pemasaran hasil produksi terhadap 
produktivitas adalah sebesar 0,315 .

6) Pengaruh langsung variabel penerbitan SKU terhadap kinerja adalah sebesar 0,298 .

7) Pengaruh langsung variabel produktivitas terhadap kinerja adalah sebesar 0,228 .

b. Pengaruh Tidak Langsung (Indirect Effect)

1) Pengaruh tidak langsung variabel konsultasi bisnis melalui produktivitas terhadap kinerja $(0,731 \times 0,358)=0,255$

2) Pengaruh tidak langsung variabel fasilitas pemasaran hasil produksi melalui produktivitas terhadap kinerja $(0,5 \times 0,315)=0,157$

3) Pengaruh tidak langsung variabel penerbitan SKU melalui produktivitas terhadap kinerja $(0,431 \times 0,298)=0,128$

\section{Interpretasi}

Interpretasi hasil penelitian ini terbagi menjadi empat kelompok, yaitu pengaruh langsung variable $\mathrm{X}$ (Konsultasi bisnis $\mathrm{X}_{1}$, Fasilitas pemasaran hasil produksi $\mathrm{X}_{2}$, pelatihan keterampilan kerja $\mathrm{X}_{3}$, dan penerbitan $\mathrm{SKU} \mathrm{X}_{4}$ ) terhadap produktivitas $Y_{2}$, pengaruh langsung variable $\mathrm{X}$ (Konsultasi bisnis $\mathrm{X}_{1}$, Fasilitas pemasaran hasil produksi $\mathrm{X}_{2}$, pelatihan keterampilan kerja $\mathrm{X}_{3}$, dan penerbitan SKU $\mathrm{X}_{4}$ ) terhadap kinerja $Y_{1}$, pengaruh langsung produktivitas $Y_{2}$ terhadap kinerja $Y_{1}$, dan pengaruh tidak variable $\mathrm{X}$ (Konsultasi bisnis $\mathrm{X}_{1}$, Fasilitas pemasaran hasil produksi $\mathrm{X}_{2}$, pelatihan keterampilan kerja $\mathrm{X}_{3}$, dan penerbitan $\mathrm{SKU} \mathrm{X}_{4}$ ) terhadap kinerja $Y_{1}$ melalui produktivitas $Y_{2}$.

\section{a. Pengaruh Konsultasi bisnis $\mathrm{X}_{1}$ Terhadap produktivitas $Y_{2}$ usaha mikro di Kabupaten Jember.}

Pengujian jalur pertama tentang pengaruh variabel Konsultasi bisnis $\mathrm{X}_{1}$ terhadap produktivitas $Y_{2}$, dengan nilai signifikansi sebesar 0,008. Nilai signifikansi sebesar 0,008 lebih kecil dari $\alpha(\mathrm{p}<0,05)$, menunjukkan bahwa konsultasi bisnis $\mathrm{X}_{1}$ berpengaruh signifikan terhadap produktivitas $Y_{2}$. Maka $\mathrm{H}_{1}$ didukung. Hal ini menunjukkan bahwa semakin baik konsultasi bisnis yang dilakukan maka, semakin positif pula produktivitas. 


\section{b. Pengaruh Fasilitas pemasaran hasil produksi $X_{2}$ Terhadap produktivitas $Y_{2}$ usaha mikro di Kabupaten Jember.}

Pengujian jalur kedua tentang pengaruh variabel Fasilitas pemasaran hasil produksi $\mathrm{X}_{2}$ terhadap produktivitas $Y_{2}$, dengan nilai signifikansi sebesar 0,002 . Nilai signifikansi sebesar 0,002 lebih kecil dari $\alpha(\mathrm{p}<0,05)$, menunjukkan bahwa Fasilitas pemasaran hasil produksi $\mathrm{X}_{2}$ berpengaruh signifikan terhadap produktivitas $Y_{2}$. Maka $\mathrm{H}_{2}$ didukung. Hal ini menunjukkan bahwa semakin baik Fasilitas pemasaran hasil produksi $\mathrm{X}_{2}$ yang dilakukan maka, semakin positif pula produktivitas.

\section{c. Pengaruh pelatihan keterampilan kerja $X_{3}$ Terhadap produktivitas $Y_{2}$} usaha mikro di Kabupaten Jember.

Pengujian jalur ketiga tentang pengaruh variabel pelatihan keterampilan kerja $\mathrm{X}_{3}$ terhadap produktivitas $Y_{2}$, dengan nilai signifikansi sebesar 0,226 . Nilai signifikansi sebesar 0,226 lebih besar dari $\alpha(\mathrm{p}<0,05)$, menunjukkan bahwa pelatihan keterampilan kerja $\mathrm{X}_{3}$ tidak berpengaruh signifikan terhadap produktivitas $Y_{2}$. Maka $\mathrm{H}_{3}$ tidak didukung. Hal ini menunjukkan bahwa keterampilan kerja tidak membawa pengaruh terhadap produktivitas usaha mikro di Kabupaten Jember.

\section{d. Pengaruh penerbitan SKU $X_{4}$ Terhadap produktivitas $Y_{2}$ usaha mikro di}

\section{Kabupaten Jember.}

Pengujian jalur keempat tentang pengaruh variabel penerbitan SKU $\mathrm{X}_{4}$ terhadap produktivitas $Y_{2}$, dengan nilai signifikansi sebesar 0,029. Nilai signifikansi sebesar 0,029 lebih kecil dari $\alpha(\mathrm{p}<0,05)$, menunjukkan bahwa penerbitan SKU X 4 berpengaruh signifikan terhadap produktivitas $Y_{2}$. Maka $\mathrm{H}_{4}$ didukung. Hal ini menunjukkan bahwa penerbitan $\mathrm{SKU} \quad \mathrm{X}_{4}$ membawa pengaruh terhadap produktivitas usaha mikro di Kabupaten Jember.

\section{e. Pengaruh Konsultasi bisnis $X_{1}$ Terhadap keberlanjutan Kinerja $Y_{1}$} komunitas JEKA di Kabupaten Jember.

Pengujian jalur kelima tentang pengaruh variabel Konsultasi bisnis $\mathrm{X}_{1}$ terhadap kinerja $Y_{1}$, dengan nilai signifikansi sebesar 0,001 . Nilai signifikansi sebesar 0,001 lebih kecil dari $\alpha(\mathrm{p}<0,05)$, menunjukkan bahwa konsultasi bisnis 
$\mathrm{X}_{1}$ berpengaruh signifikan terhadap kinerja $Y_{1}$. Maka $\mathrm{H}_{5}$ didukung. Hal ini menunjukkan bahwa semakin baik konsultasi bisnis yang dilakukan maka, semakin positif pula keberlanjutan kinerja komunitas JEKA di Kabupaten Jember.

\section{f. Pengaruh Fasilitas pemasaran hasil produksi $\mathrm{X}_{2}$ Terhadap keberlanjutan} Kinerja $Y_{1}$ komunitas JEKA di Kabupaten Jember.

Pengujian jalur keenam tentang pengaruh variabel Fasilitas pemasaran hasil produksi $\mathrm{X}_{2}$ terhadap Kinerja $Y_{1}$, dengan nilai signifikansi sebesar 0,002. Nilai signifikansi sebesar 0,002 lebih kecil dari $\alpha(\mathrm{p}<0,05)$, menunjukkan bahwa Fasilitas pemasaran hasil produksi $\mathrm{X}_{2}$ berpengaruh signifikan terhadap Kinerja $Y_{1}$. Maka $\mathrm{H}_{6}$ didukung. Hal ini menunjukkan bahwa semakin baik Fasilitas pemasaran hasil produksi $\mathrm{X}_{2}$ yang dilakukan maka, semakin positif pula keberlanjutan kinerja komunitas JEKA di Kabupaten Jember.

g. Pengaruh pelatihan keterampilan kerja $X_{3}$ keberlanjutan Kinerja $Y_{1}$ komunitas JEKA di Kabupaten Jember.

Pengujian jalur ketujuh tentang pengaruh variabel pelatihan keterampilan kerja $\mathrm{X}_{3}$ terhadap Kinerja $Y_{1}$, dengan nilai signifikansi sebesar 0,448. Nilai signifikansi sebesar 0,448 lebih besar dari $\alpha(\mathrm{p}<0,05)$, menunjukkan bahwa pelatihan keterampilan kerja $\mathrm{X}_{3}$ tidak berpengaruh signifikan terhadap Kinerja $Y_{1}$. Maka $\mathrm{H}_{7}$ tidak didukung. Hal ini menunjukkan bahwa keterampilan kerja tidak membawa pengaruh terhadap keberlanjutan kinerja komunitas JEKA di Kabupaten Jember.

h. Pengaruh penerbitan $\mathrm{SKU} \mathrm{X}_{4}$ Terhadap keberlanjutan Kinerja $Y_{1}$ komunitas JEKA di Kabupaten Jember.

Pengujian jalur kedelapan tentang pengaruh variabel penerbitan SKU $\mathrm{X}_{4}$ terhadap Kinerja $Y_{1}$, dengan nilai signifikansi sebesar 0,031. Nilai signifikansi sebesar 0,031 lebih kecil dari $\alpha(\mathrm{p}<0,05)$, menunjukkan bahwa penerbitan SKU X 4 berpengaruh signifikan terhadap Kinerja $Y_{1}$. Maka $\mathrm{H}_{8}$ didukung. Hal ini menunjukkan bahwa penerbitan $\mathrm{SKU} \mathrm{X}_{4}$ membawa pengaruh terhadap keberlanjutan kinerja komunitas JEKA di Kabupaten Jember.

i. Pengaruh produktivitas $Y_{2}$ Terhadap keberlanjutan Kinerja $Y_{1}$ komunitas JEKA di Kabupaten Jember. 
Pengujian jalur kesembilan tentang pengaruh variabel produktivitas $Y_{2}$ terhadap kinerja $Y_{1}$, dengan nilai signifikansi sebesar 0,049. Nilai signifikansi sebesar 0,049 lebih kecil dari $\alpha(\mathrm{p}<0,05)$, menunjukkan bahwa produktivitas $Y_{2}$ berpengaruh signifikan terhadap kinerja $Y_{1}$. Maka $\mathrm{H}_{9}$ didukung. Hal ini menunjukkan bahwa semakin baik produktivitas $Y_{2}$ yang dilakukan maka, semakin positif pula keberlanjutan kinerja komunitas JEKA di Kabupaten Jember

j. Pengaruh Konsultasi bisnis $\mathbf{X}_{1}$, Fasilitas pemasaran hasil produksi $\mathbf{X}_{2}$, pelatihan keterampilan kerja $\mathbf{X}_{3}$, penerbitan $\quad$ SKU $\quad \mathbf{X}_{4}$ Terhadap keberlanjutan Kinerja $Y_{1}$ komunitas JEKA di Kabupaten Jember melalui produktivitas $Y_{2}$.

Variabel Konsultasi bisnis $\mathrm{X}_{1}$, Fasilitas pemasaran hasil produksi $\mathrm{X}_{2}$, pelatihan keterampilan kerja $\mathrm{X}_{3}$, penerbitan $\mathrm{SKU} \mathrm{X}_{4}$ selain berpengaruh langsung juga berpengaruh secara tidak langsung terhadap Terhadap keberlanjutan Kinerja $Y_{1}$ komunitas JEKA di Kabupaten Jember melalui produktivitas $Y_{2}$. Setelah dilakukan uji analisis jalur, terdapat variabel bebas yang tidak berpengaruh signifikan terhadap produktivitas $Y_{2}$ maupun Kinerja $Y_{1}$.

Berdasarkan analisis Triming Theory, variabel yang tidak berpengaruh maka dapat dihapus dan didapat hasil seperti dibawah ini

1. Pengaruh tidak langsung variabel konsultasi bisnis $X_{1}$ melalui produktivitas terhadap kinerja $(0,731 \times 0,358)=0,255$. Maka, nilai dari pengaruh tidak langsung antara variabel konsultasi bisnis $\mathrm{X}_{1}$ melalui produktivitas terhadap kinerja adalah sebesar 0,255

2. Pengaruh tidak langsung variabel fasilitas pemasaran hasil produksi $\mathrm{X}_{2}$ melalui produktivitas terhadap kinerja $(0,5 \times 0,315)=0,157$. Maka, nilai dari pengaruh tidak langsung antara variabel fasilitas pemasaran hasil produksi $\mathrm{X}_{2}$ melalui produktivitas terhadap kinerja adalah sebesar 0,157 .

3. Pengaruh tidak langsung variabel penerbitan $\mathrm{SKU} \mathrm{X}_{4}$ melalui produktivitas terhadap kinerja $(0,431 \times 0,298)=0,128$. Maka, nilai dari pengaruh tidak langsung antara variabel penerbitan $\mathrm{SKU} \mathrm{X}_{4}$ melalui produktivitas terhadap kinerja adalah sebesar 0,128 .

Dengan demikian, maka dirasa perlu untuk komunitas JEKA di Kabupaten Jember 
melakukan suatu pembaruan atau peningkatan fungsi dari kegiatan tersebut.

\section{Kesimpulan}

Berdasarkan hasil analisis maka dapat ditarik beberapa poin kesimpulan dari penelitian ini, yaitu sebagai berikut:

1. Konsultasi bisnis $X_{1}$ berpengaruh positif signifikan terhadap produktivitas $Y_{2}$ usaha mikro di Kabupaten Jember.

2. Fasilitas pemasaran hasil produksi $X_{2}$ berpengaruh positif signifikan terhadap produktivitas $Y_{2}$ usaha mikro di Kabupaten Jember.

3. Pelatihan keterampilan kerja $\mathrm{X}_{3}$ tidak berpengaruh terhadap produktivitas $Y_{2}$ usaha mikro di Kabupaten Jember.

4. Penerbitan SKU $\mathrm{X}_{4}$ berpengaruh positif signifikan terhadap produktivitas $Y_{2}$ usaha mikro di Kabupaten Jember.

5. Konsultasi bisnis $X_{1}$ berpengaruh positif signifikan terhadap keberlanjutan Kinerja $Y_{1}$ komunitas JEKA di Kabupaten Jember.

6. Fasilitas pemasaran hasil produksi $\mathrm{X}_{2}$ berpengaruh positif signifikan terhadap keberlanjutan Kinerja $Y_{1}$ komunitas JEKA di Kabupaten Jember.

7. Pelatihan keterampilan kerja $X_{3}$ tidak berpengaruh terhadap keberlanjutan Kinerja $Y_{1}$ komunitas JEKA di Kabupaten Jember.

8. Penerbitan $\mathrm{SKU} \mathrm{X}_{4}$ berpengaruh positif signifikan terhadap keberlanjutan Kinerja $Y_{1}$ komunitas JEKA di Kabupaten Jember.

9. Produktivitas $Y_{2}$ berpengaruh positif signifikan Terhadap keberlanjutan Kinerja $Y_{1}$ komunitas JEKA di Kabupaten Jember.

\section{Saran}

Upaya pembinaan berupa pendampingan agar sesuai bagi komunitas JEKA untuk mampu memenuhi ketentuan, Pasal 1 Peraturan Pemerintah No. 80/2019 memenuhi persyaratan izin usaha, izin teknis, tanda daftar perusahaan, nomor pokok wajib pajak, kode etik bisnis, dan standardisasi produk. Peraturan Pemerintah Nomor 80 Tahun 2019 tentang Perdagangan melalui Sistem Elektronik dimaksudkan untuk menciptakan kesetaraan antara pelaku perdagangan daring dan luring. Namun, sejumlah ketetentuan dalam peraturan yang berlaku sejak diundangkan pada 25 Nopember 2019 itu justru dianggap menyulitkan pelaku 
usaha mikro, kecil, dan menengah atau UMKM, serta berpotensi menghambat perkembangan perdagangan secara elektronik atau e-dagang yang tengah tumbuh. Sesuai dengan undang-undang nomor 32 Tahun 2004 tentang pemerintahan daerah maka pembinaan usaha mikro menjadi tugas dan tanggung jawab pemerintah daerah. Pemerintah daerah melimpahkan tugas pembinaan usaha tersebut kepada Dinas Koperasi dan Usaha Mikro sebagai unsur pelaksana otonomi daerah. Pembinaan yang dilakukan dapat berupa konsultasi bisnis, fasilitasi pemasaran hasil produksi, pelatihan keterampilan, dan penerbitan SKU.Persoalan yang kemudian muncul adalah apakah pembinaan yang dilakukan Dinas Koperasi dan Usaha Mikro Kabupaten Jember tersebut efektif atau tidak.

\section{DAFTAR PUSTAKA}

Alwi Hasan, dkk. 2005. Kamus Besar Bahasa Indonesia.Jakarta : Departemen Pendidikan Nasional Balai Pustaka

Anoraga, Pandji. 2007. Pengantar Bisnis: Pengelolaan Bisnis dalam Era. Globalisasi. Jakarta: Rineka Cipta.

Arikunto. 2006. Prosedur Penelitian Suatu Pendekatan Praktek. Jakarta : Rineka Cipta

A.W. Widjaja. 2002. Komunikasi dan Hubungan Masyarakat. Jakarta : PT. Bumi Aksara

Ghozali, Imam. 2011. Aplikasi Analisis Multivariate dengan Program SPSS. Semarang : Badan Penerbit Universitas Diponegoro

Indikator Kinerja Utama Dinas Koperasi dan Usaha Mikro Kabupaten Jember Tahun 2018

Ivancevich, John, M, dkk. 2008. Perilaku dan Manajemen Organisasi Jilid 1dan 2. Jakarta : Erlangga

Mathis. Robert L. Dan Jackson, John H. 2002. Manajemen Sumber Daya Manusia. Jakarta : Salemba Empat

Peraturan Bupati Jember Nomor 43 Tahun 2016 Tentang Kedudukan Dinas Koperasi dan Usaha Mikro Kabupaten Jember

Peraturan Pemerintah Republik Indonesia Nomor 32 Tahun 1998 tentang 
Pembinaan dan Pengembangan Usaha Kecil

Peraturan Pemerintah Nomor 80 Tahun 2019 tentang Perdagangan melalui Sistem Elektronik tentang Perdagangan melalui Sistem Elektronik

Santoso, Singgih. 2007. Statistik Deskriptif: Konsep dan Aplikasi dengan Microsoft Excel dan SPSS. Bandung : PT. Remaja Rosadakarya

Sugiyono. 2004. Metode Penelitian. Bandung : Alfabeta

Sugiyono. 2005. Metode Penelitian Bisnis. Bandung : Alfabeta

Sugiyono. 2013. Metode Penelitian Kuantitatif, Kualitatif dan R\&D. Bandung : Alfabeta

Sulistyawati, Praba. 2011. Analisis Pengaruh Citra Merk dan Produk Keputusan Laptop Merek Acer di Kota Semarang. Universitas Diponegoro Semarang

Supranto J. 2003. Metode Riset dan Aplikasinya Dalam Pemasaran, Edisi Ketujuh.Jakarta : Rineka Cipta

Undang-undang Pemerintah Republik Indonesia Nomor 20 Tahun 2008 tentang Usaha Mikro, Kecil, dan Menengah 